\title{
Development of iconic spot replications in Kampoeng Heritage Kajoetangan as learning media for indische empire culture for tourists
}

\author{
L. Sidyawati*, J. Sayono, S.D. Anggriani \& M.N.L. Khakim \\ Universitas Negeri Malang, Malang, Indonesia \\ J.K.B. Ali \\ Universiti Teknologi Mara, Malaysia
}

\begin{abstract}
One of the Indische Empire-style cultures left from the Dutch era whose existence can still be seen and studied and whose artifacts are yet passed down from generation to generation in Malang City is Kampoeng Heritage Kajoetangan. This village is located on Jalan Jend, Basuki Rachmat Gg. VI, Kauman, Kec. Klojen, Malang City, East Java. Situated in an alley in a heritage building area, this village is one of the tourist villages frequented by children, adolescents and adults. It has houses from the Dutch colonial era and is occupied by their owners. This village consists of three hamlets, each of which has iconic assets, namely Rumah Namsin, Rumah Jacoeb, and Kali Sukun. These icons need to be introduced to the younger generation as part of the history of Malang City. To make it easier to recognize the icons, researchers developed a replica using the Borg and Gall development model, which simplified the process into four steps taking into account the time available, namely Research and Information Collecting, Planning, Developing the Preliminary Form Product and Final Product Revision. The results of this research are (1) the replica of the interior of the Rumah Namsin, (2) the replica of the exterior of the Rumah Namsin, (3) the replica of the interior of the Rumah Jacoeb, (4) the replica of the exterior of the Rumah Jacoeb and (5) Replica of the Kali Sukun and Jembatan Semeru.
\end{abstract}

Keywords: replica, iconic, kampoeng heritage kajoetangan, learning media, indische empire, culture

\section{INTRODUCTION}

Culture is a way of life formed from many elements such as knowledge systems, language, technology and equipment systems, art systems, livelihood systems, religious systems, and social systems in a group of people or society. Selo Soemardjan and Soeleman Soemardi (1964) state that culture is everything that is created by humans both tastes and creations. Culture is inherited from generation to generation and an inseparable part of human life. In historical records, the occurrence of inherited culture from generation to generation can be investigated by tracing back the various legacies that are still left.

One of the cultures whose existence can still be seen and studied and the artifacts that are yet passed down from generation to generation in Malang City is Kampoeng Heritage Kajoetangan. This village is located in the heart of the city, precisely on Jalan Jendral Basuki Rachmat Gg. VI, Kauman, Klojen, Malang City, East Java. This village is one of the tourist villages frequently visited by children, adolescents, and adults. It has houses from the Dutch colonial era occupied

*Corresponding author: lisa.sidyawati.fs@um.ac.id 
by their owners. The interview results conducted by the researcher, with the head of the Tourism Awareness Group (Pokdarwis), reveal that there were 60 old houses identified in this village. The houses are relatively preserved in their original forms.

After the researchers conducted field observations on 60 houses identified in the Kampoeng Heritage Kajoetangan, the houses were classified to have an Indische Empire style. Indische Empire style is the influence of Dutch colonial architectural styles in Indonesia from the mid-18th century to the early 19th century. This style was lifted from French architecture, which was later brought by Governor-General Herman Willem Daendels to Indonesia. The application of the Indische Empire style in Indonesia was adapted to climat conditions and the availability of materials (Handinoto \& Soehargo 1996).

However, the field's problem is that visitors can take selfies in front of the house or inside, but the educational content is still lacking. There are no relevant learning materials regarding the cultural reconstruction of Kampoeng Heritage Kajoetangan until they became the relics we see today. The results of interviews with tourists also discover that sometimes they are not always able to enter the house and see the inside details. Tourists are also no longer able to reconstruct how the house was once arranged and intended. Therefore, researchers feel the need to develop learning media through the replication of this heritage building so that later visitors who come here and take selfies in front of or inside the house can also learn about the reconstruction of the past of how this house was used.

\section{METHODS}

Developing a replica of a house icon in Kampoeng Heritage Kajoetangan as a learning medium for Indische Empire culture for this tourist followed the Borg \& Gall development model. The reason for choosing the Borg and Gall (2003) development model was that the steps in this study follow the initial concept of development that the researcher had carried out. Sukmadinata (2006) explains that the Borg and Gall development model contains ten steps for implementing a research and development strategy. In this study, it was simplified into four phases, considering the limited time of the research. Those phases included research and information collecting. At this stage, the researcher made observations in the Kampoeng Heritage Kajoetangan to collect data to identify problems in the tourist village to find solutions to visitors' questions. Besides this, researchers also collected data about heritage buildings used as replicas for the learning materials. The second stage was planning, where the researcher arranged work steps and alternative solutions if problems in preparing the application occurred, along with the solutions to the issues. The third stage was to develop a preliminary form of the product. At this stage, the researchers measured and created a 3D building design that would be realized as a replica and developed an iconic replica of the Kampoeng Heritage Kajoetangan building. In this stage, the replica was made with a specific scale precisely the same as the original building. During the final product revision, the speakers' last input of results was refined to become the finished product.

\section{RESULTS AND DISCUSSION}

Kampoeng Heritage Kajoetangan is an area designated as a cultural heritage area by the government of Malang City. This village tour offers cultural tourism that contains historical education by showing the Dutch colonial heritage house's architecture in the Indische Empire style, which is still maintained until today. Indische means like Indies or Indies. Indischgast or Indischman, in Dutch, means a Dutch person who used to live in Indonesia for a long time. Hij is Indisch means he has Indonesian blood. Indisch culture is a mixture of European, Indonesian, and specific Peranakan Chinese culture (Milone 1966), which emerged primarily as an architectural expression in the mid-18th and 19th centuries. It was originated from European bachelors living in Indonesia and their concubinage or marriage to Indonesian, Eurasian or Chinese women. However, the prototype 
of this culture grew due to the relationship between European men who took the mistresses of Indonesian female domestic servants (Nyai) and formed a family (Milone 1966).

Building architecture, outdated equipment, or other items are also available in this area, such as ontel bicycles, cooking utensils, lamps, windows, cameras, telephones and other home furnishings. Kayutangan village also keeps many remains of past civilizations in the form of shopping buildings, the tomb of Eyang Honggo Kusumo, the Tandak cemetery, the Krempyeng market, Dutch irrigation channels, waterways, "thousand stairs" and other points of high historical value in Malang (Khakim 2019). The houses and colonial heritage buildings in the Indische Empire style were transformed into replicas. It serves as one of the learning media for tourists so that tourists not only go around the village and take selfies but can also get information about the reconstruction of the buildings. It also explains its main function when the building was used. With this learning media, tourists can imagine seeing themselves in the past and living with the Kayutangan people in colonial times. Gerlach and Ely (1971) said that the media, when understood in broad terms, is human, material, or events that build conditions that enable students to acquire knowledge, skills or attitudes. Media is used in the field of teaching or education so that the term becomes educational media or learning media. While students, in this case, are tourists visiting Kampoeng Heritage Kajoetangan. Furthermore the benefits of learning media are also stated by Sudjana and Rivai (2002), that using teaching media can enhance student learning in teaching, which in turn is expected to increase the learning outcomes they achieve.

The researcher only took three iconic heritage buildings representing three hamlets to be replicated due to research time limitations. The selected building icon represents the economic system, technology systems, equipment and the ordinary social systems in the Dutch colonial era. Those heritage icons are: (1) Rumah Namsin, (2) Rumah Jacoeb, and (3) the Kali Sukun irrigation channel flanked by the Semeru Tunnel in the north and Talun in the south.

\subsection{Replica of the interior and exterior of the Rumah Namsin}

Rumah Namsin is located at Jalan Basuki Rahmad No. 31, Malang City. The logo of the Kampoeng Heritage Kajoetangan was taken from this house building. Rumah Namsin is estimated to have been founded in the 1900s, and the first owner was a Dutchman named V. Doorene. In 1924, Rumah Namsin was purchased by a Dutch national named L. C. Verhey, and this building was used as a motorcycle dealership under the Indian, Harley, Douglas and F.N brands and sold parts for Ford cars. When the Japanese came to Indonesia, the Verhey family left Indonesia and returned to
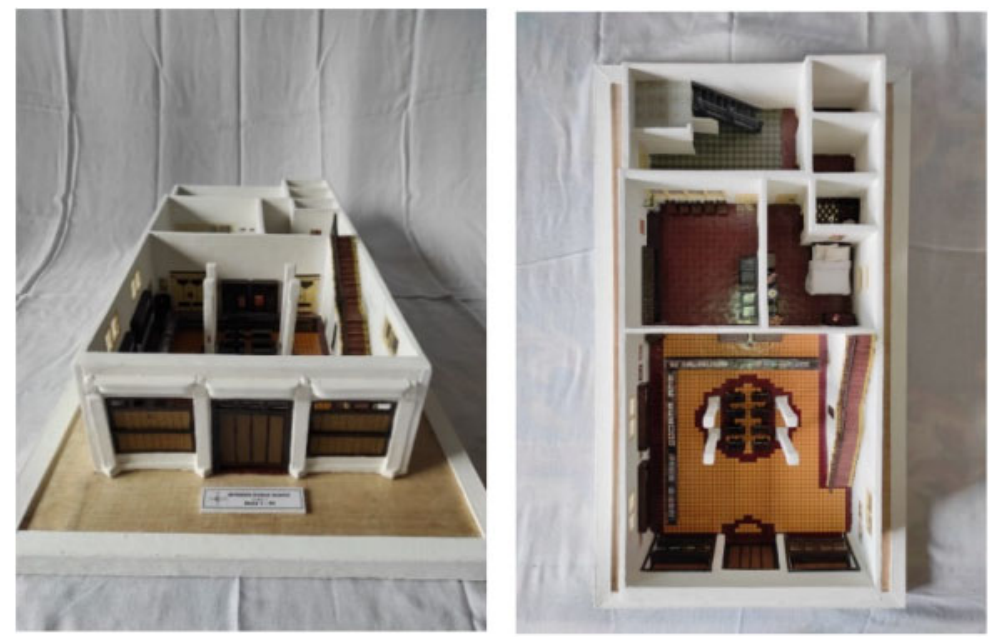

Figure 1. Replica of the Interior of the 1st Floor of the Rumah Namsin. 

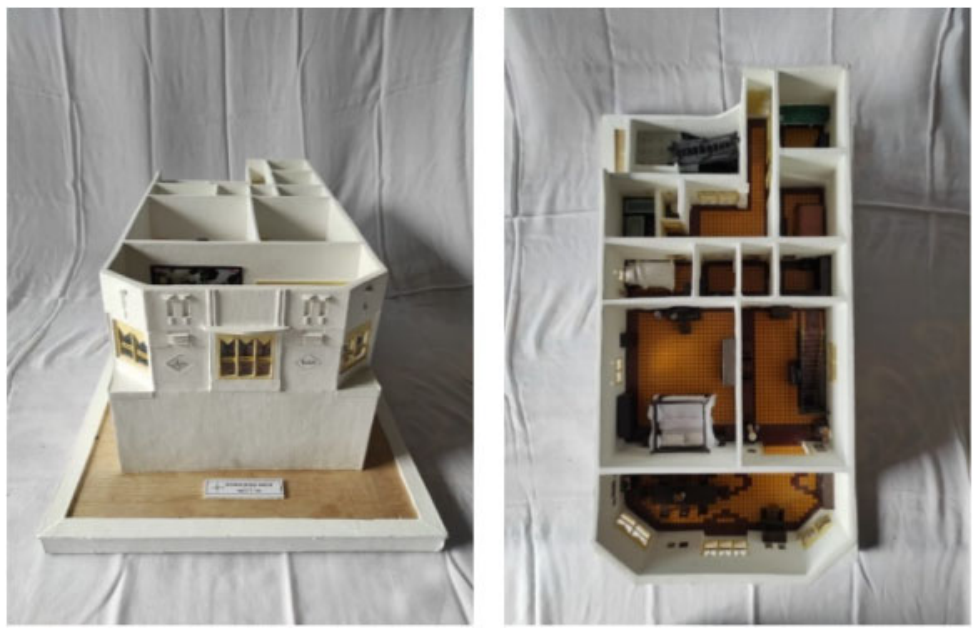

Figure 2. Replica of the Interior of the 2nd Floor of the Rumah Namsin.
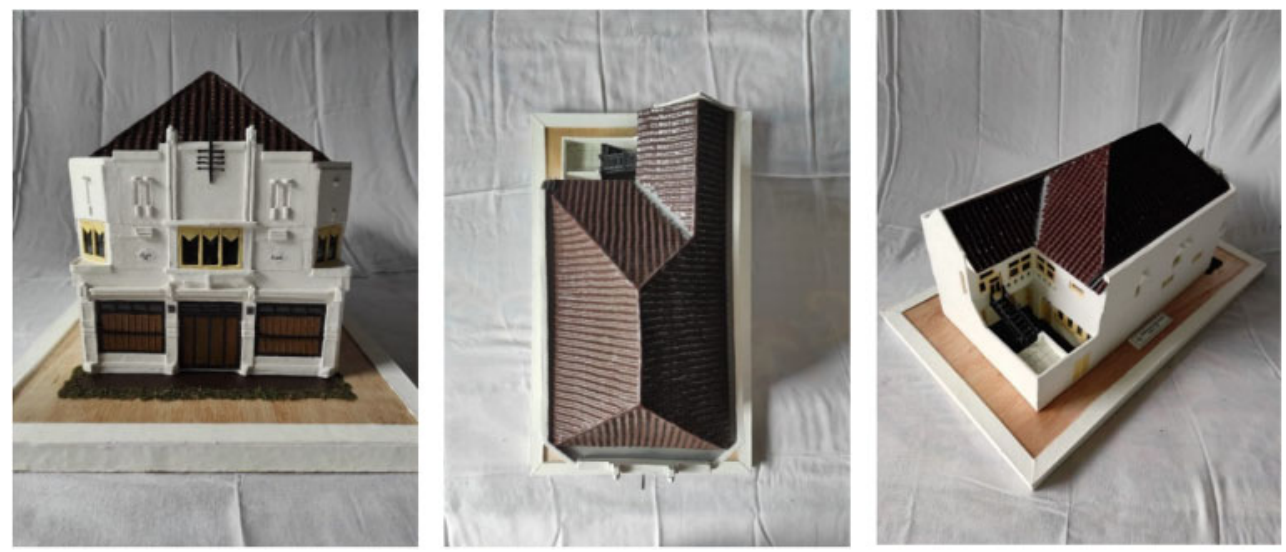

Figure 3. Replication of Rumah Namsin's Exterior.

Rotterdam in the Netherlands. The Japanese took over Rumah Namsin as a tribute deposit office. After Indonesia's independence in 1950, this house was bought by the Namsin family, and used it as a Singer sewing machine shop and for the production of ice lollies. In the 1975's, they sold the house through a broker named Wen Zhen. After Wen Zhen, this house was bought by Siho Ismanto (Liem Zhong Hoo). This house was repaired and returned to its original form.

In the 1978, this house was finally restored and began to be occupied again. Since then, this house has been used as a private residence and is not used for trading. The furniture inside is also obtained from Siho's colleagues, ranging from chairs and tables to cupboards of various sizes. In 2006, Siho fell ill. This house was vacated because he and his wife were old and had difficulty climbing stairs to the 2nd floor. On March 18, 2011, Siho Ismanto died in a hospital in Surabaya. He was finally buried in Kepanjen cemetery, Malang. His wife named Lilik Tamiati (Tan Mee Swen), eventually moved to a house located at Jalan K.H. Hasyim Ashari No. 30, Malang.

In 2015, Siho Ismanto's son named Suyono (Liem Ting Soen), planned to restore this building's heritage atmosphere. This house was painted and refurbished. In the middle of 2016, this house began to be used once a week on Fridays for Divine Services. Since then, the Rumah Namsin has 
become known by the residents of Malang City as a historical house, until today this house has always been controlled every day. The replica sizes for this Rumah Namsin are $46.8 \mathrm{~cm}$ in length, 27 $\mathrm{cm}$ in width, and $35 \mathrm{~cm}$ high. The tools and materials used to manufacture these replicas included plywood, paperboard, wood glue, cork, mica plastic, cardboard, acrylic paint, brushes, cutters and scissors.

\subsection{Replica of interior and exterior of the Rumah jacoeb}

Rumah Jacoeb is one of the old buildings in Kampoeng Heritage Kajoetangan, which was still maintained in its original form (structure and some furniture) until now. Rumah Jacoeb is located at Jl. AR. Hakim II No. 1193. It was built around 1920, with the owner Jacoeb, who was a Padangnese who bought a Javanese house in Kayutangan in 1930. Jacob was a level 1 draftsman in the government who also had a hobby of painting. The results of his paintings are still firmly displayed on the walls in his house. When viewed from above, the shape of this house building is a triangle. This house has an area of $113 \mathrm{~m} 2$ with a building area of $60 \mathrm{~m} 2$. There has never been any change from the beginning until now, including the "thump" in front of the house. The Jacoeb family used the "thump" that looks like a horse saddle as a piece of furniture to relax and chat in the afternoon with neighbors. The lower "saddle" is a chair, and the upper "saddle" is a table where coffee, tea, and snacks are placed. This house was initially gray, but the owner changed it to brown. The table and chairs in this house are Vanderpool Limensen.
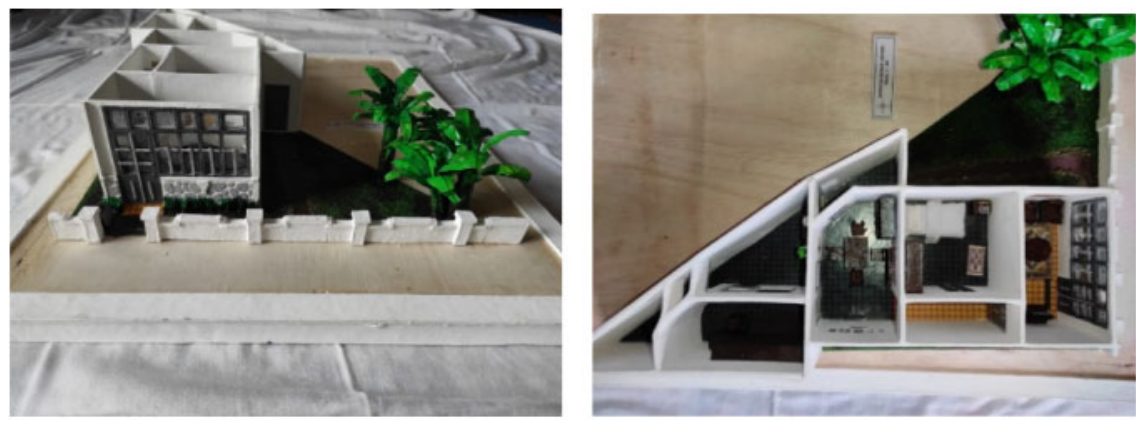

Figure 4. Replication of Rumah Jacoeb's Interior.
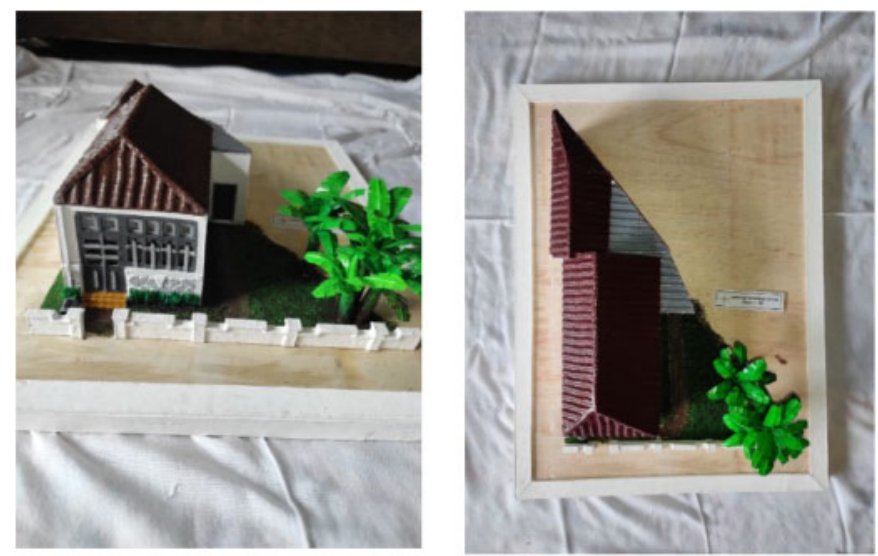

Figure 5. Replication of Rumah Jacoeb's Eksterior. 


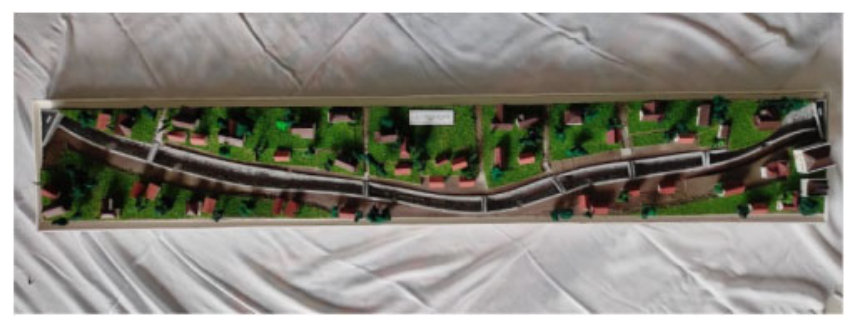

Figure 6. Replica of the Kali Sukun and Semeru Tunnel.

The replica sizes for this Rumah Jacoeb are in $40 \mathrm{~cm}$ length, $29 \mathrm{~cm}$ width, and $20 \mathrm{~cm}$ high. The tools and materials used to manufacture these replicas include plywood, paperboard, wood glue, cork, mica plastic, cardboard, acrylic paint, brushes, cutters and scissors.

\subsection{Irrigation channel}

Malang City is an area on the bend of the Brantas River, where during the Dutch era, a fort was built on the left side of the Brantas River and is now called the Klojen area (Ridjal et al. 2016). The irrigation channel around the Kampoeng Heritage Kajoetangan comes from a river break centered in the Oro-oro Dowo area. The irrigation channel was built during the reign of the Dutch East Indies and is still being maintained today. There are about six river shards in the underground passage and are still active today. One of the river fragments in the Kampoeng Heritage Kajoetangan area, named Kali Sukun, also flows to the Kebon Agung sugar factory in Malang and flows to the rice fields around the Sawahan area (currently Sawahan Petrol Station). Not many things have been changed from the Kali Sukun irrigation channel in the Kampoeng Heritage Kajoetangan. The current situation is being repaired to avoid flooding because of the river's shallowness (H. Udin). This Kali Sukun is located around the Talun, Kauman, and Kasin areas (Schaik 1996).

Inside the Kampoeng Heritage Kajoetangan, there is an irrigation channel. The irrigation channel became a barrier between the colonial housing area (Jl. Tengger, Jl. Dorowati, Jl. Arjuna) and indigenous housing. Indigenous housing is arguably older than colonial housing. Indigenous housing was also formerly owned by the colonialists, who then often changed its ownership. Colonial housing is assumed to have existed since Bouwplan V (the 1920s), which focused on development in the Talun area. During those years, European immigrants arrived, requiring the government to provide them with a place to live. It is even more iconic because there are two tunnels at both ends of the channel in the Kayutangan area, namely the Semeru tunnel in the north and the Talun tunnel on the south side. The two tunnels support the road bridge in Malang City, whose building structure is still maintained today.

This irrigation canal's replica sizes are in $110 \mathrm{~cm}$ length, $18 \mathrm{~cm}$ in width, and $13 \mathrm{~cm}$ high. The tools and materials used to manufacture these replicas include plywood, paperboard, wood glue, cork, mica plastic, cardboard, acrylic paint, brushes, cutters and scissors.

\section{CONCLUSION}

This replica of the iconic spot in the Kampoeng Heritage Kajoetangan is a learning medium for learning about the Indische Empire culture for tourists that provides educational information. This replica has succeeded in modernizing the delivery of information about cultural artifacts of colonial heritage, which initially could only be seen from the outside and became selfie spots. It has become a replica where tourists can reconstruct past events from when these spots were still used for activities during the colonial period. In the future, the replica of the iconic spot in Kampoeng Heritage Kajoetangan will be used by other researchers with more detailed information and equipped with more innovative technologies. 


\section{REFERENCES}

Borg \& Gall. 2003. Education Research. New York: Allyn and Bacon.

Frampton, Kenneth.1985. Modern Architecture A Critical History. Thames And Hudson Ltd: London

Gerlach, Vernon S. \& Donald P. Ely. 1971. Teaching \& Media: A Systematic Approach. Second edition. New Jersey: Prentice Hall, Inc.

Handinoto. 2009. Indische Empire Style: Gaya Arsitektur “Tempo Doeloe” yang Sekarang sudah Mulai Punah. Jurnal Dimensi, 3(1), 35-45.

Handinoto \& Soehargo, P. H. 1996. Perkembangan Kota \& Arsitektur Kolonial Belanda di Malang. Yogyakarta: ANDI.

Khakim, Nurfahrul Lukmanul. 2019. Urgensi Pengelolaan Pariwisata Kampung Heritage Kajoetangan Malang. Jurnal Teori dan Praksis Pembelajaran IPS, 4(2) 15-22.

Milone, Pauline D. 1966a. Qeen City of the East: Metamorphoses of a Colonial Capital, Berkley. University Of California. Phd: Thesis.

Milone, Pauline D. 1966b. Indische Culture And Its Relationship to Urban Life. Jurnal Comparative Studies In Society \& History, Vol. 9, 407-426.

Perdana, Andini. 2019. Naskah La Galigo: Identitas Budaya Sulawesi Selatan di Museum La Galigo. Pangadereng: Jurnal Hasil Penelitian Ilmu Sosial Dan Humaniora, 5 (1), 25-38.

Ridjal, Abraham Mohammad. 2016. Building Form berdasarkan Sejarah Kawasan Bangunan pada Jalan Basuki Rahmat Malang. Jurnal RUAS, Vol. 14 No 2. 1-15.

Seminar Nasional Seni Dan Desain: "Reinvensi Budaya Visual Nusantara”. Jurusan Seni Rupa dan Jurusan Desain Universitas Negeri Surabaya.

Soemardjan, Selo \& Soelaeman, S. 1964. Setangkai Bunga Sosiologi. Jakarta: Lembaga FE-UI.

Sudjana, Nana \& Rivai, Ahmad. 2002. Media Pengajaran. Bandung: Sinar Baru OFFSET

Sukmadinata, Nana Syaodih, 2006. Metode Penelitian Pendidikan. Bandung: PT. Remaja Rosdakarya.

Van Schaik, A. 1996. Malang. Beeld van een Stad. Purmerend Asia Maior. 